\title{
Forskningsbibliotekerne mellem to kommissioner
}

\author{
Af Leif Thorsen
}

Nogle trak $i$ danske forskningsbibliotekers udvikling $i$ de sidste 50 år, belyst ved en sammenligning mellem Betankning vedrorende Statens Biblioteksvasen (1927) og Biblioteksbetankningen 1979.

I forrige århundrede dækkede betegnelsen kommission de to synonyme begreber i vort århundrede - udvalg og kommission. En kommission nedsættes $\mathrm{i}$ dag som led i et lovforberedende arbejde, medens et udvalg ikke behøver at have et så målrettet sigte. Begge afslutter deres arbejde med en betænkning, som samler overvejelserne $\mathrm{i}$ en række forslag, men det er lovgiverne eller de administrative myndigheder, der afgør, om forslagene føres ud i livet.

Kommissioners betydning er følgeligt varierende. Er deres tanker i pagt med tiden, sætter de umiddelbare spor. Nogle betænkninger bliver omgående fejet af bordet, fordi tankerne er for nye, og først på et senere tidspunkt bliver de accepteret. Men hvis ingen tager en kommissions overvejelser alvorligt, er arbejdet da forgæves? Jeg tror det ikke. Det kan aldrig skade at fă idealerne, målene, defineret og opstillet. Alene denne proces vil styrke retningslinierne, også fordi det er praktisk at have dem samlet, $i$ hånden, $i$ en trykt betænkning.

Indenfor biblioteksområdet har vi på ca. 130 år haft tre store betænkninger til at fastlægge retningslinierne. Er det meget? På den

Leif Thorsen, forstebibliotekar. Det kgl. Bibliotek, Christians Brygge 8, 1219 København K. 


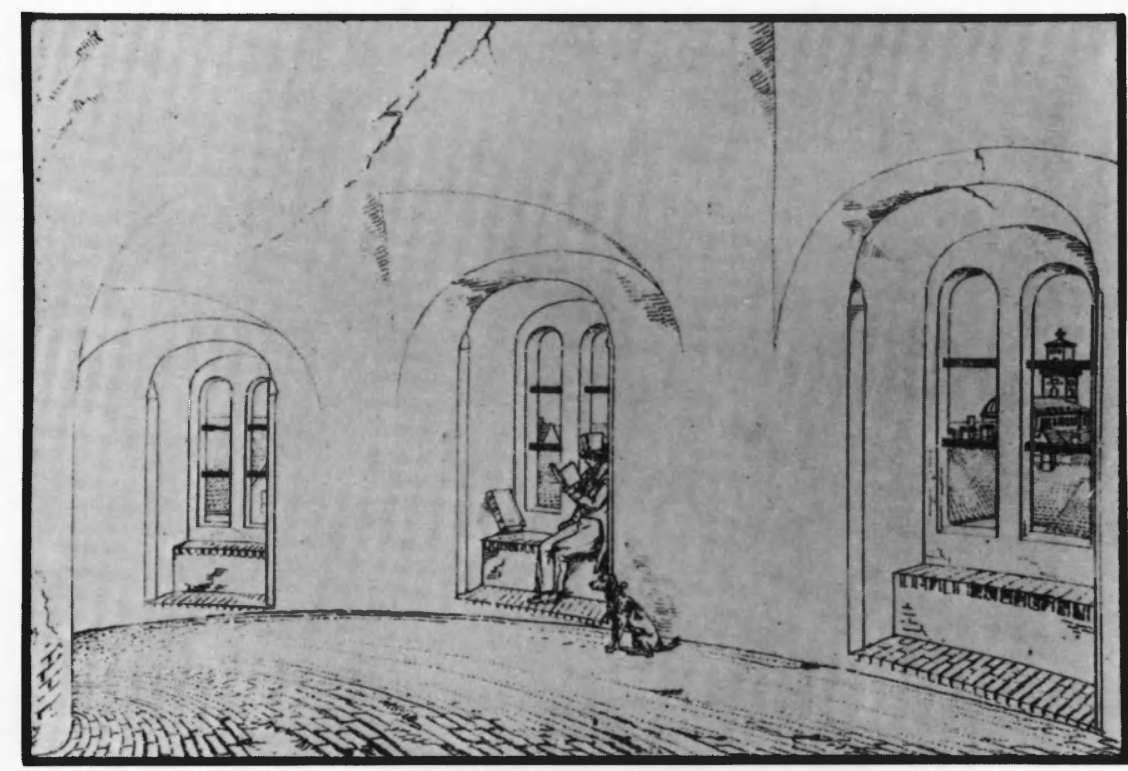

For at komme op til indgangen til Universitetsbibliotekets bogsal over hvalvingerne $i$ Trinitatis Kirke, en indgang, der lå ca. 18 meter over gadeniveauet, måtte man til fods. Tegning af Jens Holm, en son af.H. G. F. Holm, kaldet Fattig-Holm. Det kgl. Bibliotek, Billedsamlingen.

ene side kan man sige, at principperne må have været gode, siden de har været så holdbare; på den anden side kan man også sige, at vort område har været relativt betydningsløst, siden ingen ulejligede sig med at foretage hyppigere justeringer for at løse de problemer, som betænkningerne ofte pegede på var af gammel dato.

Selv om jeg her kun vil behandle 1927- og 1979-betænkningerne, må jeg dog for kontinuitetens skyld begynde med at nævne nogle træk fra betænkningen, som blev resultatet af den bibliotekskommission, der nedsattes i 1848; blandt dens medlemmer var Det kgl. Biblioteks og Universitetsbibliotekets ledere og repræsentanter fra Det Classenske Bibliotek og Universitetet. I det referat af 1848 kommissionens overvejelser, som findes i den første af de to betænkninger, vi her skal behandle, træffer vi to problemer, som siden, og i et mindre omfang også før, har været på forskningsbib- 
liotekernes dagsorden: fagdelingen og det indbyrdes samarbejde under en falles ledelse. 1848-kommissionens betænkning, konciperet af Madvig som Universitetets bibliotekar, citeres i spørgsmålet om fagdelingen: "... visse Videnskabsfag forudsættes i det hele hos os at have et saa indskrænket Publikum, at det $\mathrm{i}$ dem ... kan være tilstrækkeligt, at de alene vedligeholdes ved ét af de offentlige Biblioteker ... Med Hensyn til saadanne Fag kunde da de andre Biblioteker efter Omstændighederne enten aldeles undlade Anskaffelse af didhørende Skrifter eller indskrænke sig til enkelte Haandbøger og Oversigtsværker eller hyppigere benyttede Kildeskrifter". 1848kommissionen tillægger derefter Universitetsbiblioteket hovedopgaven medicin og naturhistorie, "... i det ringeste i zoologisk Retning ", fordi botanik hørte til det i 1752 oprettede Botanisk Haves bibliotek. Landøkonomisk litteratur henvistes til Det Classenske Bibliotek. Det kgl. Biblioteks rolle blev dobbelttydig; dels skulle det fortsat være "det overveiende Hovedbibliotek ", dels skulle det $\mathrm{i}$ sine anskaffelser indordne sig som et led i helheden. (1, s. 9)

Til løsning af spørgsmålet om et overordnet, koordinerende organ, som skulle føre tilsyn med boganskaffelserne, nedsatte Madvig, der var blevet kultusminister, en komité, den permanente komité. Den bestod af de tre ovennævnte bibliotekers ledere. Den havde ingen synlig virkning. (1, s. 10) Så vidt det har kunnet efterspores, ser det ud til, at dens sidste møde afholdtes 1864, og fagdelingen blev heller ikke realiseret ad anden vej.

Opgaven for 1924-udvalget, Udvalget vedrorende Statens Biblioteksvasen, bestod navnlig af to dele. For det første skulle det fastsætte retningslinier for landets dengang tre videnskabelige statsbiblioteker, Det kgl. Bibliotek (KB), Universitetsbiblioteket (UB) og Statsbiblioteket (SB) i Ărhus, dels for forholdet mellem dem indbyrdes, dels for deres forhold til på den ene side folkebibliotekerne, på den anden side special- og fagbibliotekerne og laboratoriebibliotekerne ved universitetet. For det andet skulle udvalget se på samarbejdet om anskaffelser, på pligtaflevering, anvendelse af dubletter, avisaflevering og kassation. $(1$, s. 1$)$

I betænkningens indledning gøres opmærksom på, at 1924-udvalget ikke har fầet til opgave at foreslå besparelser på budgetterne. 
På den anden side er udvalgets nedsættelse ingenlunde uden forbindelse med økonomiske overvejelser; vanskeligheder med hensyn til plads, personale og annua tvinger udvalget til at vurdere, om det enkelte bibliotek ved en aflastning på nogle områder kunne anvende kræfter på andre, således at man ved en nyordning kunne undgå eller formindske krav om forhøjede annua. Rammerne skulle med andre ord være uændrede, men der kunne ske omfordelinger inden for disse. $(1$, s. 5$)$

Medlemmer af 1924-udvalget blev, som formand, undervisningsministeriets departementschef K. Glahn, ved sin død i 1925 afløst af ministeriets nye chef, F. Graae og, blandt de ti øvrige medlemmer, KB's, UB's og SB's chefer, hver med sin håndgangne mand samt to repræsentanter for det nyligt oprettede Statens Bibliotekstilsyn, biblioteksdirektør Th. Døssing og biblioteksinspektør Svend Dahl. (1, s. 1)

Bibliotekskommissionen af 1976 blev nedsat som et led i udformningen af en national informations- og bibliotekspolitik og skulle "stille forslag om de ændringer i dansk biblioteksvæsens målsætning og struktur, som er nødvendige for at de offentlige bibliotekers ressourcer både samfundsøkonomisk og kulturpolitisk kan anvendes så hensigtsmæssigt som muligt ". Kommissionen skulle desuden behandle spørgsmålet om de overordnede organer, som bør indgå $\mathrm{i}$ det offentlige biblioteksvæsens struktur, herunder specielt $\mathrm{i}$ relation til den centrale administration af folke- og forskningsbiblioteksvæsenet og forskningsbibliotekernes fremtidige struktur og styrelse. En undersøgelse af samarbejdet mellem de forskellige bibliotekstyper, men også en drøftelse af den nødvendige grænsedragning mellem deres virkeområder og opgaver, indgik i kommissoriet. Endelig skulle 1976-kommissionen drøfte folkebibliotekernes målsætning, struktur, økonomi og indkøbs- og kassationspolitik. (2, s. 3)

I 1976-kommissionen sad, med departementschef O. PerchNielsen som en fremragende formand, ialt 19 medlemmer, næsten dobbelt så mange som i 1924-udvalget. Af professionelle biblioteksfolk var der ialt ni, blandt dem rigsbibliotekaren, overbibliotekaren for SB og biblioteksdirektøren; fem af de øvrige var udpeget 
af Danmarks Biblioteksforening (fire) og Bibliotekarforbundet (en). Blandt resten af medlemmerne fandtes dels amts- og kommunalpolitikere med organisatorisk tilknytning til biblioteksvæsenet, først og fremmest gennem Danmarks Biblioteksforening, dels ministerielle repræsentanter. (2, s. 6) Jeg tør i øvrigt karakterisere kommissionen som absolut biblioteksvenlig.

\section{Bibliotekspolitiske betragtninger}

Inden jeg går over til at behandle nogle konkrete forskningsbiblioteksfaglige områder, hvis udvikling jeg mener i særlig grad påkalder sig opmærksomheden, vil jeg fremlægge nogle bibliotekspolitiske betragtninger over disse 50 års forløb.

Alene forskellen mellem de to betænkningers fysiske omfang viser, hvor kompliceret en sag biblioteksvæsenet er blevet i forhold til tidligere. Sammenligner vi kun de umiddelbart tilgængelige akter, ser vi, at 1924-udvalgets betænkning med bilag fylder ca. 250 sider, 1976-kommissionens ca. 375 sider; hertil kommer specialudvalgenes betænkninger, som tilsammen når op på ca. 1140 sider, ialt godt 1500 sider. Lægger vi dertil de knap 80 sider utrykt bilagsmateriale, som en kreds af forskningsbibliotekarer udsendte, kan vi stille 250 sider op mod 1600. En signifikant forskel, selv når vi tager i betragtning, at 1976-kommissionen behandlede folkebibliotekerne mere indgående. Den omstændighed, at det i 1976 fandtes nødvendigt at bede henimod 150 mennesker fra biblioteksvæsenet og beslægtede institutioner om at udarbejde de otte specialbetænkninger, på hvilke hovedbetænkningen kom til at bygge, belyser også mangfoldigheden ved arbejdet. Men mere end det, det belyser også det politiske perspektiv, herunder nærdemokratiets krav.

Dog først: hvoraf kommer nu denne kompleksitet? Svaret er kendt og kan derfor kort begrundes i de sidste årtiers viden-vækst og øgede krav til uddannelse, som nu også omfatter mange flere end tidligere; bibliotekerne har skullet forsøge at følge dette op. Det er i første række lykkedes for folkebibliotekerne, som har haft større politisk opbakning end forskningsbibliotekerne; i og omkring folkebibliotekernes virke finder vi derfor navnlig væksten og dermed det sammensatte. Vi finder det også, som anført, i forsk- 
ningsbibliotekernes virksomhed, også de er jo vokset de sidste 1015 år. For begge sektorers vedkommende ville tal for økonomi, personale og udlån kunne illustrere denne udvikling.

Jeg mener, at årsagen til, at så mange beskæftigede sig med forskningsbibliotekerne $\mathrm{i}$ forbindelse med 1976-kommissionen og de mange sider om dem, mindre skal søges $\mathrm{i} ø$ ønsket om oversigt over et komplekst og voksende område, oprustning af det og kurslægning end $\mathrm{i}$ ønsket om ændrede styringsformer og arbejdsmetoder. Her lå den egentlige interesse hos 1976-kommissionen for forskningsbibliotekerne; interessen var politisk i egentlig forstand.

Hermed forlader vi betragtningerne over kompleksiteten og går over til det bibliotekspolitiske perspektiv.

\section{Den politiske interesse}

Lad mig i den henseende først betragte 1924-udvalgets nedsættelse. Hartyani har behandlet departementschef Glahns overvejelser over eventuelle udvalgsmedlemmer og deres kvalifikationer, som for øvrigt efter Glahns mening skulle bære præg af reformvenlighed. Det var Glahn, der afgjorde sagen uden anden nævneværdig debat end den, der foregik i hans hoved. Den eneste politiker, der var inddraget i sagen, var ministeren, der jo havde det sidste ord. (6, s. 79)

Ganske anderledes i 1976. Der var særdeles megen diskussion omkring udpegningen af hovedkommissionens medlemmer, fremkaldt af Danmarks Biblioteksforenings ønske om stort set alene at præge kommissionsarbejdet. Foreningens iver, og dermed karakteriserer jeg også den politiske iver, opstod for folkebibliotekernes vedkommende dels af interesse for og opmærksomhed mod en institution, der kulturelt følte sig friere og vejede tungere end før, dels fordi tyngden efterhånden også var af økonomisk art.

For forskningsbibliotekernes vedkommende gjaldt det som ovenfor nævnt fælles arbejdsmetoder, herunder rationalisering, og administrativ og anden form for fællesskab med folkebibliotekssektoren.

Selv om det falder lidt uden for rammerne, kan jeg som medlem af 1976-kommissionen ikke lade være med at nævne en iagttagelse, 
jeg gjorde om politikernes arbejde med forskningsbiblioteksproblemer i kommissionen. De havde alle, gennem deres beskæftigelse med de kommunale folkebiblioteker, så at sige fået biblioteksvæsenet $\mathrm{i}$ kroppen, de havde lært at håndtere en sådan ting, desværre sommetider med en manglende forståelse for, at de indlærte greb ikke altid kunne anvendes over for forskningsbibliotekerne. Hermed er politikernes indsats i kommissionsarbejdet i øvrigt ikke karakteriseret fuldt ud. Det er min mening, at de gjorde en god indsats, mest på folkebibliotekssiden. Her viste de progressivitet, omend af forskellig grad. Uden at forklejne andre vil jeg især fremhæve R. Lysholt Hansens og Thorkild Simonsens engagement.

Der er endnu to $i$ en bredere forstand politisk betonede træk i forskningsbibliotekernes udvikling mellem de to kommissioner, som jeg vil omtale inden de mere håndgribeligt faglige.

I 1924-udvalget tænkte naturligvis ingen på biblioteksudvalg, som de kendes i styrelsesloven af $1973 \$ 10$, hvor repræsentanter for personalet og for såvel interne som eksterne brugere har indflydelse på udarbejdelsen af de berørte forskningsbibliotekers budgetforslag, deres indkøbspolitik og fordelingen af bøger mellem læreanstaltens hovedbibliotek og institutbibliotekerne. En konsekvens af disse biblioteksudvalg er 1976-kommissionens flertals forslag om at udvide deres antal til at galde alle forskningsbiblioteker, der betjener en højere uddannelsesinstitution, og at udvide deres kompetence til også at omfatte indsigt med opslag og ansøgere til forskningsbibliotekarstillinger, med ændringer i publikumsbetjeningen og til at sikre, at der gennemføres vejledning i biblioteksbenyttelse. $(2$, s. 101) Den autoritære ledelsesform, som i sin tid var en selvfølge, lakker nu mod enden. Her spiller både kompleksiteten, som gør det umuligt for en enkelt at styre alt, og den politiske interesse, i dette tilfælde navnlig placeret hos medarbejderne, ind.

Det andet træk er dette: Forskningsbibliotekernes opgave har altid været at indsamle, opbevare og formidle. Formidlingsprocessen er i dag trådt stærkere $i$ forgrunden. Fra ret passive samlinger har de nu udviklet sig til aktive informationscentre. De henvender sig ikke blot til specialister og forskere, der søger speciel litteratur, men i dag mere end tidligere til mennesker med mange forskellige 
uddannelser og meget forskellige behov for viden og information, som 1976-kommissionen bemærker. (2, s. 22) Derfor har vi også $i$ de sidste årtier set pr-afdelinger dukke frem, på KB i 1965, i SB 1972. (2, s. 95) Det nye i dette udadvendte træk i forskningsbibliotekernes historie må dog i sandhedens interesse reduceres en smule: ved UB's indvielse i salen over Trinitatis kirke i 1657, som bivånedes af Frederik 3., åbnedes ved et sindrigt maskineri på én gang de øverste døre i bogskabene, hvorved biblioteket i ét syn præsenteredes for publikum! (7, s. 334)

Jeg går nu over til de mere håndgribelige faglige emner - idet jeg erkender, at grænsen kan være vanskelig og forekomme kunstig at drage. Det ses alene af de to første emner, jeg vil behandle.

\section{Fallesdirektorat for folke- og forskningsbiblioteker}

Samarbejdet med folkebibliotekerne har udviklet sig stærkt i den mellemliggende periode. Også det formaliserede; i 1965 etableredes Fællesudvalget for Folke- og Forskningsbiblioteker. I 1977 gik der fra finansudvalget til forskningsbibliotekerne en større bevilling til edb-arbejde på betingelse af samarbejde på dette felt med folkebibliotekerne. Uden i øvrigt at komme nærmere ind derpå må også nævnes det samarbejde mellem de to bibliotekssektorer og med skolebibliotekerne, der finder sted i Bibliotekscentralen og til dels i Indbindingscentralen. Allerede 1924-udvalget skriver, at nok kan man tale om to hovedområder, men grænserne er i høj grad flydende. "Hvor trækker man i det enkelte Tilfælde den bestemte Grænse mellem Videnskab og Oplysning, mellem videnskabelig Litteratur og Oplysningslitteratur «? (1, s. 20) Udvalget "finder det derfor indlysende, at Opgaven maa være ud fra Enhedssynspunktet at fastsætte de enkelte Faktorers, de enkelte Bibliotekers og Bibliotekstypers Plads inden for Systemet ... og at foreslaa de nødvendige Foranstaltninger til Sikring af det gensidige Samarbejde ..." (1, s. 21) Helhedsbiblioteksvæsenet, men i det tætte og formaliserede samarbejdes form. Denne holdning bekræftes andetsteds i betænkningen, hvor kommissionen finder det rigtigst at opretholde den administrative adskillelse mellem statslige og kommunale biblioteker. Den skriver: "Trods den Enhed indenfor hele det offentlige 
Biblioteksvæsen, som allerede eksisterer og som Udvalget tillægger den allerstørste Værdi, ville der nemlig nødvendigvis til Behandling $\mathrm{i}$ et Fællesorgan komme til at foreligge en Mængde Spørgsmaal af saa speciel Interesse for Biblioteker af henholdsvis den ene og den anden Gruppe, at det, om end de efter deres Karakter bør behandles som Fællessager for den paagældende Gruppe, vilde være ganske hensigtsløst at behandle dem som Fællesanliggende $i$ et Organ, omfattende begge Grupper. " (1, s. 167)

I 1976-kommissionen tog flertallet, med de principielt samme argumenter som i 1924, konsekvensen af disse og foreslog samarbejdet udvidet til integration. Som et nyt argument omtaler 1976kommissionen dog, at den generelle samfundsudvikling i mange henseender har bevirket en udviskning af skarpe konturer; det gælder bl.a. fagområder og uddannelsesgrupper, som danner forudsætninger for bibliotekernes virksomhed og deres hidtidige inddeling i bibliotekstyper. Kommissionen peger på, at nyere forskningsbiblioteker ved deres lokaleindretning med åbne hylder og med deres indkøb af flere eksemplarer af den samme titel i et vist omfang ligner store folkebiblioteker. "Man kan derfor rejse det generelle spørgsmål, om der stadig kan påvises væsentlige forskelle imellem bibliotekstyper, og om der bør tilstræbes en afgrænsning af de forskellige bibliotekers opgaver«. (2, s. 20)

Falles styrelse af forskningsbibliotekerne

Allerede i 1842 i Københavns Universitets årbog udtalte Madvig som universitetsbibliotekar sig for det hensigtsmæssige $i$, at UB og KB koordinerede deres køb af store og kostbare værker: "... men endnu bedre var det, om disse Institutter stode under samme overordnede Auctoritet, uden hvilket hiint ikke let vilde blive stadig Vedtægt «. (3, s. 412)

1924-udvalget foreslog oprettelsen af et fællesorgan for forskningsbibliotekerne: Fællesraadet for de videnskabelige Biblioteker under Undervisningsministeriet. Det skulle rådgive ministeren og fungere som forum for samarbejdet mellem bibliotekerne; men det skulle ikke fungere som overledelse af samtlige biblioteker, f.eks. skulle de enkelte bibliotekers budgetter ikke forelægges rådet. Det 
var i det hele taget ikke hensigten at gøre indgreb $\mathrm{i}$ bibliotekernes selvstyre ud over, hvad der var nødvendigt for samarbejdet. (1, s. 168 og 4 , s. 17)

I sin artikel om betænkningen i Bogens Verden er Københavns stadsbibliotekar, Jens Aarsbo, meget skuffet over kommissionens manglende evne til at finde, hvad han kalder en moderne løsning på problemet vedrørende organisation og administration af statens biblioteksvæsen, nemlig en personlig, kontrollerende centralmyndighed, jævnstillet med statens tilsyn med folkebibliotekerne. Han harcellerer over kommissionens bemærkninger, som efter hans mening er "til Gunst for Separatisme og institutionelt Selvstyre», og kalder det foreslåede fællesråd en inkompetent myndighed. (8, s. 29) Aarsbo fik ret. Fællesrådet etableredes, men efter 1931 findes ikke flere indførelser $i$ forhandlingsprotokollen. (4, s. 19) Rådet døde endda efter færre års virke, end tilfældet havde været for det feellesorgan, som 1848-kommissionen skabte.

I 1943 indførtes et noget anderledes fællesorgan ved oprettelsen af Rigsbibliotekarembedet, og samordningsbestræbelserne blev yderligere styrket i 1970, da Forskningsbibliotekernes Fællesråd så dagens lys. Ingen af de to institutioner har dog formel myndighed over forskningsbibliotekerne; først 1976-kommissionen vovede at tage det afgørende skridt og foreslå oprettelsen af en egentlig forskningsbiblioteksstyrelse med den madvigske Auctoritet. Jeg tror, at blandt årsagerne til 1976-kommissionens beslutning findes én, som dog overvejende må henvises til det generelle politiske område og som vejer tungt: vi lever og virker $i$ et samfund, som på en helt anden måde end i 1924 er præget af krav om lønsomhed, effektivitet og planlægning. Det kræver styring på mange planer.

\section{Statsbiblioteket}

1976-udvalget anvendte knap én side specielt på SB, 1924-kommissionen skrev 30. Bølgerne gik højt dengang og havde gjort det $i$ flere år om SB's forhold til et eventuelt kommende universitet $i$ Århus og til folkebibliotekerne. Hvor skulle hovedvægten lægges? 1924-udvalgets flertal lagde den på SB's funktion som overcentral for folkebibliotekerne, men lod dog en mulighed stå åben for visse 
forskningsbiblioteksfunktioner. (1, s. 68) Altså overcentral først og forskningsbibliotek så. 1976-kommissionen konstaterer, at overcentralfunktionen i praksis nu først og fremmest baseres på udnyttelse af den alligevel til universitetsformål forhåndenværende bogbestand, og at varetagelsen af denne særlige funktion ikke længere er et spørgsmål om anskaffelsespolitik, men om udlåns- og forsendelsesekspertise. (2, s. 127) Altså forskningsbibliotek forst og overcentral så.

Efter at ideen om oprettelse af et stort bibliotek i provinsen opstod hos Chr. Bruun ved Christiansborg Slots brand i 1884, som truede hans bibliotek i det nuværende rigsarkivs lokaler, synes SB omsider at have fundet sin plads i dansk biblioteksvæsen. Den plads som mindretallet i 1924-udvalget, SB's egne repræsentanter, anviste det, støttet af 77 videnskabsmænd og andre interesserede, fortrinsvis fra provinsen.

\section{Fagdelingen}

Specialbibliotekerne er af gammel dato, således grundlagdes 1728 Astronomisk Observatoriums bibliotek, 1752 Botanisk Centralbibliotek, 1755 Artilleriets bibliotek, 1758 Kunstakademiets. Så fulgte etableringen af Marinens bibliotek, senere Hærstabens bibliotek, i 1783 veterinær- og landbrugsbiblioteket. (3, s. 396-397) Gennem de mange år siden har andre specialbiblioteker set dagens lys; udveksling af litteratur har skabt sådanne eller trukket grænserne op mellem de eksisterende.

Derimod er fagdelingsprincippet af betydelig yngre dato. 1848betænkningen var kun et tilløb, og den i 1918 stedfundne udveksling af jura og medicin mellem KB og UB et isoleret fænomen; der eksisterede ingen faste grænser for bibliotekernes samlerlyst. Dette forhold medførte bl.a., at publikum i mange tilfælde ikke vidste, hvor en bestemt bog skulle søges.

Derfor fandt 1924-udvalget at måtte tage sagen om den udenlandske litteraturs fordeling op til grundig behandling. Det fik inden for dette område måske sin største betydning. Adskillige biblioteker fik i de følgende år tillagt den dobbelte forpligtelse at fungere som en bestemt læreanstalts eller forskningsinstitutions biblio- 
tek og som fagligt hovedbibliotek på landsplan. Udvalget tilsigtede "... bl.a. gennem fastere Afgrænsning end hidtil af de enkelte Bibliotekers Opgaver og Virkefelt at gøre det lettere for det bibliotekssøgende Publikum at skønne om, i hvilket Bibliotek en bestemt Bog eller Bøger indenfor et bestemt Fag skal søges». (1, s. 145)

Diskussionen koncentrerede sig om KB og UB. Det bedste, skrev udvalget, ville være, hvis den mulighed forelå at skabe ét universalbibliotek som hovedbibliotek med de dertil hørende fagog institutionsbiblioteker. Derved ville man undgå vanskeligheder ved, at mange fag på visse områder griber ind i hinanden, og unødvendige dobbeltkøb ville være udelukkede. Tanken om at skabe et sådant universalbibliotek ved at sammenlægge KB og UB havde da også været fremme flere gange, sidst i 1904 i forbindelse med et forslag om opførelse af en tilbygning til universitetsbiblioteket, men var hver gang blevet afvist af praktisk betonede årsager. (1, s. 23) Universalbibliotekstanken kunne dog, mente 1924-udvalget, i praksis nærme sig sin realisering ved at fjerne de to bibliotekers opgaver så meget fra hinanden som muligt: "... med andre ord, at de to Biblioteker bliver som to Afdelinger af eet stort videnskabeligt Bibliotek, hvilke hver for sine Fag virker ogsaa som Universitetsbibliotek «. Udvalget foreslår konkret, at den udenlandske litteratur fordeles mellem de to biblioteker, således at $\mathrm{KB}$ overtager de humanistiske fag og UB medicin, matematik og naturvidenskab. (1, s. 26)

1976-kommissionen konstaterer først 1924-udvalgets afgørende rolle i denne sag. Dernæst at fagdelingen siden da har krævet revisioner, når der opstod tvivl om grænsedragning mellem fagene eller nye fag skulle indplaceres; desuden at Rigsbibliotekarembedet uanset mangel på formel myndighed har forestået sådanne revisioner. Kommissionens flertal mener, at uanset fremtidige nødvendige revisioner, foretaget af en central myndighed på forskningsbiblioteksområdet, bør strukturen med en vis fordeling af anskaffelsesansvaret på landsplan fastholdes. (2, s. 93) Måske er 1976-kommissionen lidt blødere $\mathrm{i}$ sin formulering end forgængeren, hvilket nok bunder i bedre økonomi i 1976 end i 1924, idet den anbefaler, at eksistensen af et hovedfagbibliotek for hvert fagområde ikke skal 
forhindre andre biblioteker $i$ at anskaffe faglitteratur og etablere de dokumentationstjenester, som et lokalt behov berettiger til. "Status som nationalt hovedfagbibliotek betyder en forpligtelse og skal ikke betragtes som et privilegium ". (2, s. 93)

Forud for behandlingen af fagdelingsproblematikken foreslår 1976-kommissionen, at centralbiblioteket i hvert amt skal tage initiativ til efter behov at oprette kontaktudvalg for alle et amts biblioteker, herunder forskningsbibliotekerne, for bl.a. at organisere indkøbskoordinering. (2, s. 62) Naturligt nok gentages tanken under kommissionens behandling af fagdeling; den gør dog her tillige opmærksom på, hvor vanskeligt det vil være for forskningsbibliotekerne at indgå i et sådant amtsvist samarbejde, fordi amterne ikke $i$ alle tilfælde danner rimelige rammer om en indkøbskoordinering. Måske kunne man, spørger kommissionen, inddele i andre passende regioner; en central instans for biblioteksvæsenet måtte i tilfælde af; at denne nye tanke om fagdeling skulle føres ud i livet, se herpå. (2, s. 92)

\section{Institutbiblioteker}

Det kan undre, at 1924-udvalget ikke i højere grad beskæftigede sig med institutbibliotekerne, eller laboratoriebibliotekerne, som dengang var den bibliotekstype, som kommer dem nærmest. De nævnes nu og da $\mathrm{i}$ forbindelse med andre problemer, men de trænger sig ikke på. De var ellers kommet ganske stærkt ind i biblioteksdebatten en halv snes år før og voksede i de følgende. I 1911 udsendte bibliotekar ved KB, A. A. Bjørnbo, en pjece, hvori han påviste, at boganskaffelser $\mathrm{i}$ de offentlige forskningsbiblioteker, hvilket han havde føling med som redaktør af accessionskatalogen, var præget af så stor planløshed, at op imod en trediedel af statens bogkøb var dobbeltkøb. Navnlig angreb han UB for at købe det samme som KB. (5, s. 189-190) Dets leder, Sofus Larsen, tog til genmæle; han foreholdt Bjørnbo, at han ikke skelnede skarpt mellem de offentlige bibliotekers anskaffelser og anskaffelserne til de bogsamlinger, der var opstået ved universitetets humanistiske, teologiske og samfundsvidenskabelige institutter. (5, s. 190) Litteraturen her måtte, i modsætning til det offentlige universitetsbiblioteks, altid være til 


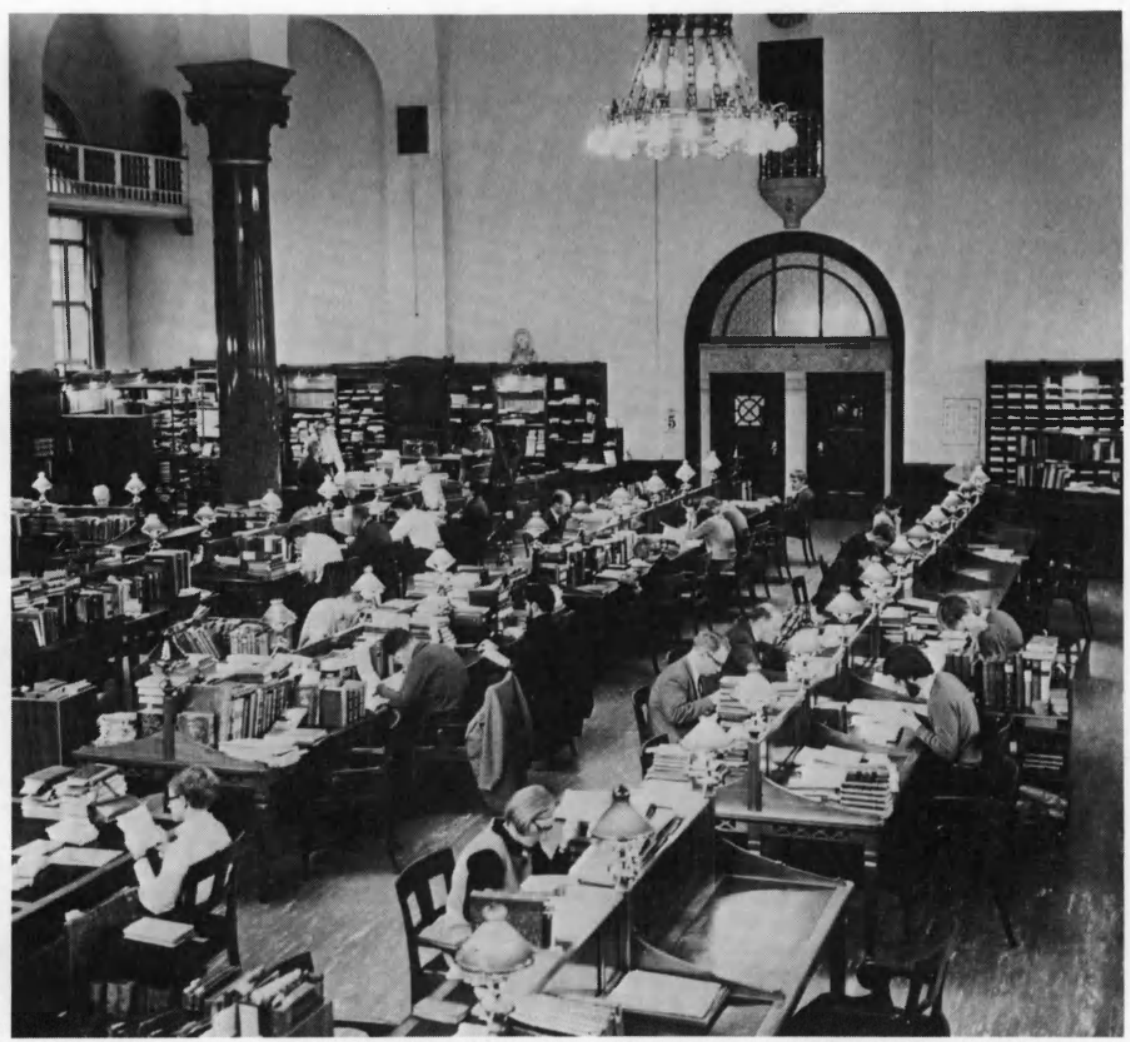

Lasesalen i Det kgl. Bibliotek, siden 1927 Kobenhavns Universitets hovedbibliotek for teologi, humaniora og samfundsvidenskab.

rådighed for de lærere og studerende, som underviste og studerede i de pågældende institutter. Den samme bogs ene eksemplar havde således ét formål $\mathrm{i}$ et institutbibliotek, det andet eksemplar et andet formål i universitetsbiblioteket.

Problemet om de to bibliotekstypers anskaffelser, tilgængeligheden af deres bogbestande og deres indbyrdes forhold i det hele taget blev også i de nu følgende år mere og mere påtrængende, fordi fagenes vækst betød en forøgelse af institutternes antal.

1976-kommissionen må konstatere, at trods mængden af insti- 
tutbiblioteker og omfanget af deres litteraturanskaffelser har der ikke været faste retningslinier for deres oprettelse og drift, ej heller for deres forhold indbyrdes eller til uddannelsesinstitutionernes hovedbiblioteker. (2, s. 99) En sammenligning, foretaget af kommissionen, viste, at for Københavns Universitets vedkommende svarede de teologiske, samfundsvidenskabelige og humanistiske fakulteters institutbibliotekers udgifter i 1975/76 til indkøb og indbinding til 32,3\% af KB's og UB's 1. afdelings (i 1960: 10,9\%), de læge- og naturvidenskabelige institutbibliotekers udgifter til disse poster til $71,8 \%$ af UB 2's. Institutbibliotekernes antal er, bemærker kommissionen, fordoblet siden 1960, og deres ressourceforbrug er i forhold til de tre hovedbiblioteker tredoblet. (2, s. 87) Enkelte institutbiblioteker er vokset $i$ en sådan grad i løbet af det seneste tiår, at de overgår de offentlige bibliotekers samlinger på det pågældende fagområde. (2, s. 137) Årsagerne til denne vakst søger kommissionen i historiske og geografiske forhold på læreanstalter og hovedbiblioteker. Navnlig hovedbibliotekernes lokale- og bevillingsforhold har spillet afgørende ind; et hovedbiblioteks ringe servicemuligheder søges der kompensation for gennem oprettelse af store institutbiblioteker. (2, s. 99)

1976-kommissionen tog hele denne sag meget alvorligt. Den ustyrede vækst faldt stærkt $\mathrm{i}$ øjnene hos alle medlemmer, men for specielt politikerne var det vigtigt at slå fast, at nok var institutbiblioteker og andre lignende biblioteker indenfor uddannelsessektoren ikke fuldt offentligt tilgængelige, men de måtte "være forpligtet til gennem de offentlige biblioteker at stille sig til rådighed for bibliotekernes indbyrdes lånevirksomhed, dersom de rummer bøger, som ikke findes i det offentlige biblioteksvæsen. Deres samlinger skal derfor være registreret $\mathrm{i}$ trykte eller på anden måde let tilgængelige fæelleskataloger. Man kunne således også betegne denne bibliotekstype som de indirekte offentligt tilgængelige biblioteker «. (2, s. 27)

At styre disse institutbiblioteker, erkendte kommissionen, var en vanskelig sag. En bevillingsmæssig koordinering mellem institutbiblioteker og hovedbibliotek veg man uden om, fordi det ville forudsætte et brud i institutternes rammebudgetter, hvis deres bib- 
lioteksposter skulle udskilles; institutternes tilpasning til forskningens og den højere undervisnings udvikling ville blive vanskeliggjort. Den nødvendige koordinering mellem institutbiblioteker og hovedbibliotek burde finde sted som et led i det generelle samarbejde med den pågældende uddannelsesinstitution, som de af kommissionens flertal (2, s. 101) foreslåede biblioteksudvalg kunne danne rammen om. (2, s. 99)

Foruden at fastsætte retningslinier for fordelingen af litteratur skulle biblioteksudvalgene afgive udtalelser til det kommende biblioteksdirektorat om institutbibliotekernes budget og regnskab vedrørende bogkøb. Direktoratet skulle i øvrigt udarbejde generelle retningslinier for den tættest mulige samordning mellem institutbiblioteker og hovedbibliotek angående anskaffelser, katalogisering, udlån, kassation m.v. (2, s. 137)

\section{Pligtaflevering}

Jeg tillader mig igen at anvende den nok ikke helt korrekte sammenligningsmetode at illustrere forskellen på et emnes behandling ved at angive forskellen i sideantal og noterer, at mens 1924-udvalget diskuterer spørgsmålet om pligtaflevering og rekvisitionsret over ca. 40 sider, bruger 1976-kommissionen godt en halv; på den foreslår den, at pligtafleveringen, $i$ lighed med hvad der er sket $i$ Sverige, udvides til også at omfatte materiale, der fremstilles i anden teknik end bogtryk, og til de forskellige former for ikke-bogligt informationsbærende materiale. (2, s. 119)

1924-udvalget giver først en fremstilling af pligtafleveringens noget forvirrede udvikling i Danmark, dernæst en oversigt over dens daværende omfang og gennemførelse og afslutter med et udførligt udarbejdet forslag til lov og bekendtgørelse om pligtaflevering. (1, s. 70) Selv om en af grundene til at nedsætte 1924-udvalget lå i nogle problemer omkring pligtafleveringen, vil det alligevel her føre for vidt at redegøre for udvalgets behandling af den. Jeg nøjes med, med 1976-kommissionens lakoniske behandling af sagen in mente, at konstatere, at den nugaldende pligtafleveringslov, det eneste udtryk for 1924-udvalgets arbejde i lovform, stort set har stået sin prøve i de 50 år, der her behandles. Dog tilføjer jeg to ting: 
Rekvisitionsretten, beføjelsen for et bibliotek til hos forlægger eller bogtrykker gratis at rekvirere de tryksager, som det måtte finde fornødent, behandles indgående for første gang i dansk bibliotekshistorie i 1924-udvalgets betænkning. Udvalget henviser til, at en sådan fremgangsmåde i mange år har været praktiseret i England, hvor der kun findes fuldstændig pligtaflevering til British Museum Library. (1, s. 83) Desuden kan vi lægge mærke til, at 1924-udvalget ingen grund fandt til at sætte spørgsmålstegn ved pligtafleveringens og rekvisitionsrettens princip, d.v.s. rimeligheden af at pålægge forlæggerne denne økonomiske byrde. For det, som for biblioteksverdenen i dag, var det blot en sag om afleveringens teknik; udvalget siger, at det for et forlag kun kan betyde meget lidt blandt de mange andre frieksemplarer, der udsendes, også at ekspedere et eller to til nogle biblioteker. (1, s. 84) Men heller ikke dengang var forlæggerne dog enige $i$ den betragtning.

\section{Depot og kassation}

Jeg tilstår, at den følgende omtale af forskningsbibliotekernes kassations- og depotproblemers behandling i de to organer falder lidt uden for den hidtil fulgte linie i og med, at jeg må konstatere, at der ingen synderlig forskel er på behandlingen af disse emner, hvilket skulle indicere, at der her ingen udvikling har været i de 50 år. Som enhver ved, er det langt fra tilfældet. Det blev påvist af ét af 1976kommissionens specialudvalg, uden at det gjorde tilstrækkeligt indtryk på kommissionen. Den omtaler kun i en enkelt sætning kassationsproblemet (2, s. 123) og er i det hele taget lidt afvisende over for oprettelsen af et fælles depotbibliotek for forskningsbibliotekerne. Det vil, siger den, principielt være en ulempe, fordi et hovedfagbiblioteks bogbestand er en afrundet helhed, som bør være samlet; det er ressourcekrævende og medfører forringet service at splitte en bogbestand ad. Pladshensyn kan dog nødvendiggøre etableringen af et fællesmagasin, måske i samarbejde med folkebibliotekernes depotbibliotek, til opbevaring af visse ældre tidsskriftrækker og disputatser. Kommissionen ender med at anbefale en nærmere undersøgelse af spørgsmålet. (2, s. 123)

1924-udvalget er trods alt mere positivt over for tanken om et 
depotbibliotek. I de tilfælde hvor der findes litteratur i et bibliotek, som praktisk taget aldrig benyttes, men som det på den anden side vil være betænkeligt at kassere, mener det, at det er naturligt at gøre som enkelte store biblioteker $i$ udlandet allerede gør: at magasinere sådan litteratur i et depot, hvorfra en bog vil kunne hentes med en à to dages varsel. Et sådant depotbibliotek bør ikke nødvendigvis ligge i København; udvalget henleder opmærksomheden på $\mathrm{Ny}-$ borg Slot eller magasinbygningen ved Korsør. (1, s. 152)

Også kassationsspørgsmålet var mod forventning mere nærværende for 1924-udvalget end for dets efterfølger, men interessen for dette tekniske spørgsmål skyldtes naturligvis politisk uvilje mod at bevilge penge til nybyggeri og udvidelser. (5, s. 217 og 6, s. 79) Udvalget siger direkte, at der er tilfælde, hvor man ikke bør vige tilbage for kassation. Endog salg af forældet litteratur nævnes, en udvej som end ikke strejfede 1976-kommissionen, men som i øvrigt ikke er et ukendt fænomen i dansk bibliotekshistorie. UB's leder, Thomas Bartholin, foranstaltede i 1675 en stor auktion, hvor han ikke blot skaffede sig af med dubletter, men også andet uønsket materiale. Auktionen over de ialt 3000 numre indbragte 650 rigsdaler, nok til en bibliotekars løn i over 5 år. (7, s. 347) 1924-udvalget bemærker dog, at salg som regel ikke vil indbringe så meget, at det kan betale sig at arrangere det, men tilføjer, at der måske ved den af udvalget anbefalede udveksling mellem KB og UB vil fremkomme dubletter af serier og enkeltværker, som med fordel vil kunne sælges i stedet for at anbringes i depot. (1, s. 152)

I modsætning til 1979-betænkningen var 1924-udvalgets betænkning genstand for omtale i adskillige blade i provins og hovedstad, hvis fremstillinger, som Bogens Verden noterede i 1927, endog i usædvanlig grad stod $i$ et besynderligt misforhold til betænkningens faktiske indhold. I Bogens Verden gennemgik Jens Aarsbo den udførligt og karakteriserede den som et stateligt mindesmærke i det danske biblioteksvæsens historie. (8, s. 21) Min sidste sammenligning mellem 1924-udvalgets og 1976-kommissionens arbejde skal på denne baggrund derfor være et spørgsmål: vil fremtiden kunne sige det samme om 1976-kommissionens betænkning? 


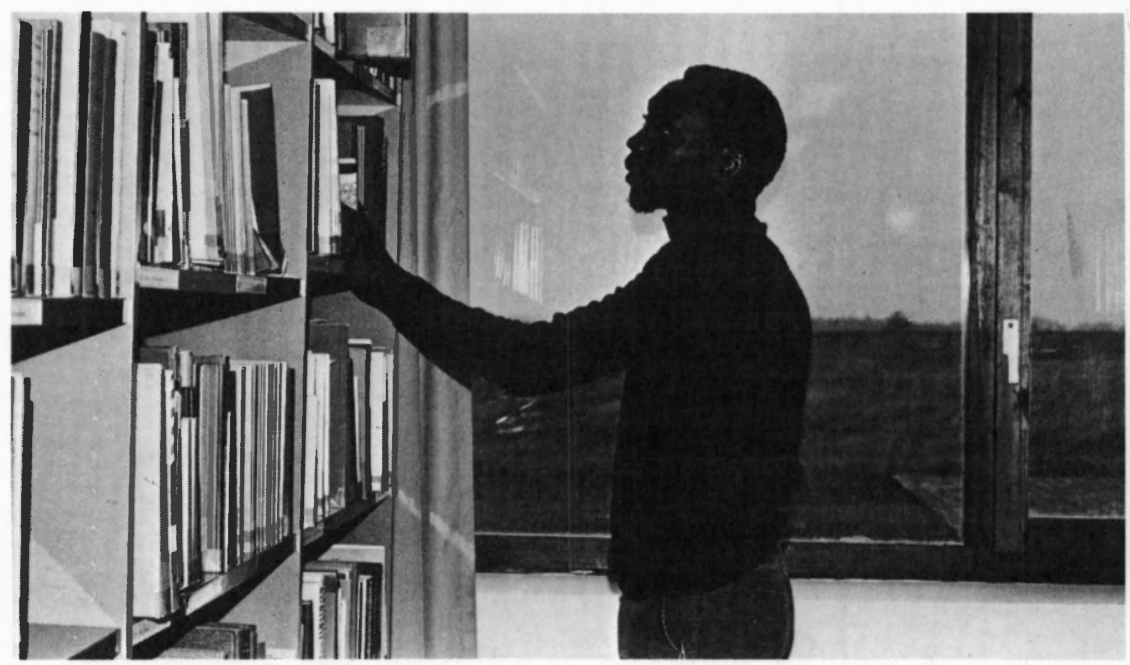

Stemningsbillede fra Roskilde Universitetsbibliotek. Foto: Leif Grage. Ca. 1976.

\section{ANVENDT LITTERATUR}

1. Betænkning vedrørende Statens Biblioteksvæsen afgiven af det af Undervisningsministeriet under 11. Oktober 1924 nedsatte Udvalg. 1927. 247 s.

2. Biblioteksbetænkningen 1979 afgivet af Bibliotekskommissionen. Betænkning nr. 878. 1979. $374 \mathrm{~s}$.

3. Palle Birkelund: Universitetsbiblioteket 1729-1926. I: Københavns Universitet 1479-1979, bd. 4. 1980. S. 365-454.

4. Marton de Hartyani: Fællesraadet for de videnskabelige Biblioteker under Undervisningsministeriet. I: Nordisk tidskrift for bok- och biblioteksväsen, bd. 68. Stockholm og Uppsala, 1981. S. 15-20.

5. Marton de Hartyani: Det mærkværdige Amfibium. I: Bibliotek for læger, bd. 174, suppl. 1. 1982. S. 181-228.

6. Marton de Hartyani: Nedsæettelsen af Biblioteksudvalget af 1924. I: Nordisk tidskrift för bok- och biblioteksväsen, bd.66. Stockholm og Uppsala, 1979. S. 79-82.

7. Harald Ilsøe: Universitetets biblioteker til 1728. I: Københavns Universitet 1479-1979, bd. 4. 1980. S. 289-364.

8. Jens Aarsbo: Statens Biblioteksvæsen. I: Bogens Verden, 9. årg. 1927. S. 21-29. 